\title{
Retornando a nossas Raízes: as ressonâncias do pensamento de García Calderón sobre a obra Raízes do Brasil de Sérgio Buarque de Holanda
}

\author{
Returning to our roots: the resonances of García Calderón's thought on the work Roots
}

of Brazil by Sérgio Buarque de Holanda

Iara Andrade Senra

Doutoranda em História Comparada/UFRJ iaravr@hotmail.com

\begin{abstract}
Resumo: O presente artigo analisa algumas possíveis ressonâncias que a obra Ideas y Impresiones (1919) de García Calderón teve sobre Raízes do Brasil (1936), de Sérgio Buarque de Holanda. Enfatizar-se-á dois pontos: a) a centralidade que Calderón reservou à questão da originalidade, ponto retomado e intensamente discutido por Buarque; b) a discussão sobre o idealismo espanhol desenvolvido por Calderón, análise que ofereceria os andaimes discursivos para Buarque conformar os tipos: Semeador e Ladrilhador. Além das fontes principais Ideas y Impresiones e Raízes do Brasil retrocedemos um pouco, selecionando obras anteriores de ambos os autores - Las Democracias Latinas de América (1912) e Originalidade Literária (1920) a fim de melhor compreender o pensamento de cada um e melhor identificar as contribuições de Calderón sobre Buarque.
\end{abstract}

Palavras Chaves: Originalidade, idealismo espanhol, praticidade portuguesa.

\begin{abstract}
This article analyzes the potential influence that the book Ideas y Impresiones (1919) by García Calderón had on Roots of Brazil (1936), by Sérgio Buarque de Holanda. Two points will be emphasized: a) the importance that Calderón reserved to the question of originality, a point intensely discussed by Buarque; $b$ ) the discussion of the Spanish idealism developed by Calderón, an analysis that would offer the discursive base for Buarque to formulate the types: "Semeador and Ladrilhador". In addition to the main sources - Ideas y Impresiones and Roots of Brazil - we went back a little, selecting previous works by both authors Las Democracias Latinas de América (1912) and Originalidade Literária (1920) in order to better understand each one's thoughts and to better identify Calderón's contributions on Buarque.
\end{abstract}

Keywords: Originality, Spanish idealism, Portuguese practicality. 


\section{Introdução}

Os povos guardam sempre as marcas de sua origem.

TOCQUEVILLE

A problemática de uma construção identitária que elevasse a imagem do sujeito nacional foi uma constante na história da América Latina. Tal anseio esteve presente em diversos ensaios ${ }^{1}$ escritos no final do século XIX e início do século XX. Para o presente artigo selecionamos dois intérpretes: o peruano Francisco García Calderón Rey (18831953) e o escritor paulista Sérgio Buarque de Holanda (1902-1982). Ambos os autores buscaram entender as peculiaridades nacionais, se lançando nas origens de nossa história. Neste mergulho, a herança ibérica teria lugar central.

Segundo Bresciani (2004), nos anos vinte, a produção cultural norteamericana/europeia foi imposta ao Brasil. E poderíamos acrescentar que não só foi imposta ao Brasil, mas também à toda América Latina, fato que contribuiu para o aumento do número de ensaios interpretativos que respondiam a tais projetos vindos de fora. Nestes ensaios, os intérpretes buscavam compreender nossas raízes, preparando a população ou para: a) absorver os princípios modernos - democracia/ liberalismo; ou para b) rechaçar tais princípios, compreendendo-os como perniciosos a realidade latinoamericana.

Ambos os projetos primavam por uma identidade a ser construída no futuro. $\mathrm{O}$ primeiro pela exclusão das tradições ibéricas/indígenas/negras para uma conseguinte absorção dos ideais modernos, o segundo por um retorno às origens, em busca de uma originalidade perdida, a ser novamente valorizada e reconquistada no porvir. A produção ensaística foi gênero expressivo de tais projetos e sua repercussão na América Latina respondia à necessidade de apresentar às nações caminhos possíveis à modernização. Isto é, trata[va]-se de explicar como progresso econômico, coesão social, instituições modernas e uma identidade nacional plausível pode[riam] ser criados a partir das condições dadas" (COSTA, 2014: 830). Logo, a tensão entre tradição e

\footnotetext{
${ }^{1}$ Texto literário, que segundo Liliana Weinberg (2001) caracteriza-se por apresentar uma interpretação bem organizada da realidade, por promover um diálogo com leituras de seu tempo, por não ser ficcional, por apresentar um caráter político, por estar pautado no ponto de vista do autor, ou seja, possui caráter subjetivo. Conforme Echevarría em El extraño caso de la estatua, os ensaios têm como objetivo de estudo privilegiado a identidade nacional.
} 
modernidade estava na ordem do dia, reproduzindo as mais diversas posições políticas e ideológicas.

Em um plano bem geral, para os ensaístas que tendiam para a valorização da tradição, o discurso girava em torno da incompatibilidade entre a realidade e os princípios modernos importados: crítica à democracia, entendia como "tirania da maioria”, crítica à ineficácia da educação e do voto universal, crítica à abstração do liberalismo, ao racionalismo positivista e ao utilitarismo yankee. Para aqueles que vislumbravam a modernidade, a ideia de progresso, de desenvolvimento industrial e ferroviário, de igualdade, de urbanização torna-se um mote.

Ante a modernidade e as tradições, Calderón e Buarque optaram pela segunda opção. Para eles, o retorno às raízes desvendaria o caráter nacional, explicaria quem somos, evidenciaria costumes que muitas vezes eram incompatíveis com as leis e hábitos importados.

No entanto é oportuno lembrar que em Buarque a opção pela valorização das tradições ibéricas em detrimento dos princípios modernos está circunscrita ao ponto de vista do autor quanto às opções de modernização. Conforme Robert Wegner (2006) salienta, Buarque era um erudito e pensava os problemas nacionais sob perspectivas diferentes. Para compreendermos melhor sua obra, devemos para tanto, considerar o momento de análise explorado pelo autor e seus diversos pontos de vista. É notório que Buarque faz dois movimentos em busca da compreensão e da modernização nacional. $\mathrm{O}$ primeiro, tomando como ponto de chegada a democracia liberal, o segundo levando em consideração a sua recusa. Obviamente que neste segundo olhar, adota uma perspectiva mais conservadora - elogia o personalismo, a ação de um líder carismático e a tendência à obediência cega do povo-. Para tanto o contexto antiliberal dos anos vinte e trinta influiu nas estratégias autoritárias apontadas pelo autor na primeira edição de Raízes do Brasil $^{2}$, assim como os expurgos que fez a tais ideias autoritárias na segunda edição (1948) testificam o contexto pós-segunda guerra mundial, momento em que retornou o prestígio dos procedimentos liberais e democráticos.

Outro ponto importante de se destacar é a contribuição que a carreira de crítico literário proporcionou aos seu estudos. Thiago Lima Nicodemo tratando especificamente das décadas em que Sérgio Buarque de Holanda se tornou crítico profissional (1940-1950) afirma que “[...] a experiência de crítico literário foi

\footnotetext{
${ }^{2}$ Para o presente trabalho utilizamos a edição princeps (1936) e a edição crítica de Raízes do Brasil (2016).
} 
fundamental para a definição de estilo e método do historiador maduro" (NICODEMO, 2014a: 27). Nicodemo relaciona este momento mais produtivo de Buarque "como crítico e historiador da literatura [...] com a fase de elaboração de algumas das suas obras mais conhecidas, como Monções, de 1945, Caminhos e Fronteiras, de 1957 [...] e [...] Visão do Paraíso" (2014a: 27).

Retrocedemos um pouco mais, aportando na década de 1920, momento em que o crítico literário ainda não é tão profissional e o historiador ainda não se fazia presente, para destacarmos umas das contribuições que a literatura hispânica proporcionaria ao ensaio Raízes do Brasil: a comparação entre América Portuguesa e Espanhola. Artigos como Originalidade Literária (Correio Paulistano, 1920) lançam luz sobre interesses e métodos que seriam caros a Buarque como crítico, ensaísta e mais tarde como historiador.

\section{La originalidad Intelectual de América (1919): a primeira comparação de Buarque entre América Espanhola/Portuguesa e o método de}

No Brasil o espetáculo divergiu bastante. Sérgio Buarque de Holanda

Sérgio Buarque de Holanda foi um exímio leitor das letras hispânicas. Interesse que perpassou a juventude ${ }^{3}$. Foi apresentado à literatura de língua espanhola por José Veríssimo ${ }^{4}$, também notável conhecedor do mundo hispano-americano. Por intermédio de resenhas escritas por Veríssimo e publicados em jornais da época, Buarque entrou em contato com diversos autores do continente, inclusive com as obras do peruano Francisco García Calderón.

Segundo Pedro Meira Monteiro (2009) com apenas dezessete anos e graças a intermediação de seu mestre Affonso Taunay, Buarque “[...] escreveria e publicaria, no Correio Paulistano, [...] um artigo intitulado "Originalidade literária". [...] Um dos autores imediatamente evocados pelo jovem articulista é o peruano Francisco García

\footnotetext{
${ }^{3}$ Para saber mais sobre a continuidade do interesse de Buarque pela Ibero-América patente em obras posteriores a Raízes, ver Passados (im)perfeitos ou a ótica buarqueana sobre o Império do Brasil na América, de Giselle Venancio e André furado.

${ }^{4}$ Veríssimo afirma ter recebido o exemplar de Las Democracias Latinas de América de Calderón, leitura que rendera a escrita do artigo Perspectivas na América Latina publicado no jornal O Imparcial, em 1912, onde apresentara a obra do autor peruano aos leitores brasileiros.
} 
Calderón, [...]” (MONTEIRO, 2009: 166). Logo, fora na década de 1920 que Buarque, ainda crítico literário, lera a obra Ideas y Impresiones (1919) de García Calderón. Leitura que lhe renderia seu primeiro artigo e revelaria interesses e análises que retornariam não só em Raízes do Brasil como também em Visão do Paraíso (1959). Além disso, em Originalidade Literária Buarque reconheceria Calderón como um dos “dos maiores pensadores críticos da América Espanhola”.

O s.r. F. García Calderón, considerado hoje, e com justiça, um dos maiores pensadores críticos da América Espanhola, estuda, num ensaio publicado recentemente Ideas y Impresiones, a originalidade literária na América, historiando detalhadamente todos os fatores que têm contribuído para a completa emancipação espiritual do Novo Mundo e, em especial, na porção onde domina a língua de Cervantes. (HOLANDA, 1996: 35-36)

Ambos os autores discutiram o tema originalidade - em princípio de ordem literária, posteriormente, dos próprios costumes, instituições e ideias políticas iberoamericanas - para tanto, destacaram as possibilidades de sua concretização futura e as interdições que sofriam no presente, devido à cópia de ideias alheias. Logo, sugestivo é o título do primeiro artigo escrito por Buarque Originalidade Literária inspirado em La Originalidad intelectual de América ${ }^{5}$ (1919) do peruano Francisco García Calderón.

Apesar de Buarque discutir o pensamento de Calderón em seu primeiro artigo e depois não mais fazer menção ao autor peruano, penso que o interesse juvenil nutrido por ele, rendera frutos. Isso porque La originalidad Intelectual de América oferecera o andaime discursivo para uma estrutura interpretativa que tomaria consistência em Raízes do Brasil (1936): a busca por uma autenticidade nacional e a comparação entre a praticidade portuguesa e o idealismo espanhol.

Em Originalidade Literária Buarque filtrou as informações de Calderón sobre o idealismo espanhol, expostos pelo autor peruano ao analisar dois poemas - Rusticatio mexicana (1782) e La Araucana (1569), e as utilizou para demonstrar que ao contrário do espanhol, o português era prático, pouco se interessava pelos indígenas e pela terra, a não ser como meio mais rápido e fácil de usufruir os benefícios do solo recémdescoberto. Mais tarde, em Raízes, fundamentou tal análise comparativa mediante o

\footnotetext{
${ }^{5}$ Terceiro artigo da obra Ideas y Impresiones. La Originalid intelectual da América apareceria pela primeira vez em 1913 compondo La creacíon de un Continente, contudo com título reduzido La Originalidad intelectual.
} 
exame de fontes como as Ordenanzas de descubrimiento nuevo e poblacion de las Indias $(1573)^{6}$, o Regimento de Tomé de Souza (1548) a Carta de Tomé de Souza $(1553)^{8}$ e mediante uma análise mais profunda, após leitura de Ética Protestante e o Espírito do Capitalismo (1904), de Max Weber, onde a "praticidade" portuguesa toma um contorno mais definido com a discussão sobre a ética da aventura.

A temática central de La originalidad intelectual de América é a busca da autenticidade. Para tanto Calderón retrocede na história, elegendo dois poemas que apresentariam indícios de uma prematura nacionalidade: Rusticatio mexicana e La Araucana.

Escrito no período colonial, o poema do padre Rafael Landivar ${ }^{9}$ (1731-1793) Rusticatio mexicana (1782) e La Araucana (publicado em três partes: 1569, 1578 e 1589), de Alonso de $\operatorname{Ercilla}^{10}$ (1533-1594) testificavam a grandeza da natureza iberoamericana anunciando um americanismo nascente "[...] en los relatos de los cronistas hay vestígios de americanismo, descripciones, evocaciones, asombro lírico ante el nuevo mundo que descubren los conquistadores" (CALDERÓN, 1919: 60). "Más arriba este monte se rasga en inmensos barrancos doquiera tendidos de altísima cumbre a las faldas profundas; empero de arbustos con tierno follaje doquiera destacan tupidos, también del añoso robledo, hasta que, depuesta la altura, por llanos tendidos su curso planea regando sembrados alegres con vítreas aguas". (LANDIVAR, s/a: 105)

Tratava-se de testemunhos de admiração e de estranheza diante de tudo aquilo que lhes era diferente. De modo que, os rios caudalosos, os bosques, a flora, a fauna, a cultura diversa contribuíam para despertar o interesse do conquistador sobre o novo mundo.

\footnotetext{
${ }^{6}$ As Ordenanzas de descubrimiento nuevo e poblacion de las Indias (1573) foram expedidas por Felipe II. O código de leis é fruto da experiência de setenta e cinco anos de penetração colonial em terras americanas e é considerado ainda hoje, o primeiro código de urbanismo da Idade Moderna. Nele estão contidas minuciosas prescrições que regulamentavam os descobrimentos (capítulo 1 a 31), os assentamentos (capítulo 32 a 137) e a pacificação indígena (Capítulo 138 a 148) da América Espanhola.

${ }^{7}$ O Regimento de Tomé de Souza é um documento jurídico sucinto que instruía o primeiro governadorgeral do Brasil quanto aos procedimentos de defesa e de povoamento da colônia portuguesa. O regimento deixa claro que a ação do Governo-geral seria complementar às dos donatários: sem maior interferência na administração das capitanias.

${ }^{8}$ Carta escrita pelo governador geral Tomé de Souza em resposta aos pedidos feitos pelo rei João III no Regimento de Tomé de Souza. Na carta o governador informava ao rei os problemas que acometiam as capitanias hereditárias.

${ }^{9}$ Rafael Landivar (Guatemala, 31 de outubro de 1731 - Itália, 27 de setembro de 1793) foi um poeta jesuíta. Fora expulso por Carlos III e nunca mais pode regressar para Guatemala, escreveu sua obra mais famosa Rusticatio mexicana no exílio na Itália.

${ }^{10}$ Alonso de Ercilla e Zúñiga (Madri, 7 de agosto de 1533 - 29 de novembro de 1594) foi um poeta e soldado espanhol, conhecido principalmente por ser o autor de La Araucana. A Araucana foi considerada por Cervantes como uma das melhores obras épicas em verso castelhano.
} 
O primeiro e mais remoto fator de originalidade literária apareceu na América com a contemplação, por parte dos europeus conquistadores, de uma nova flora mais grandiosa e magnífica do que os cercavam no ambiente primitivo: de uma fauna sob todos os aspectos mais rica e interessante que a europeia e principalmente, de nações selvagens desconhecidas até então para eles, de costumes, tradições, ideias e crenças suas. Era natural que a impressão causada pela observação onímoda convelisse as manifestações intelectuais dos conquistadores, dos moldes consuetudinários. (HOLANDA, 1996: 36)

Contudo, na visão de Buarque, difícil era afirmar que poemas como $L a$ Araucana inauguraria o americanismo em terras latino-americanas, conforme fora declarado por Calderón, isso porque os relatos dos poetas possuíam a visão dos espanhóis, não evocando, portanto, um sentimento de apreço pela nova terra. Analisando La Araucana, notamos que Ercilla, apesar de sutis elogios aos indígenas, claramente expõe os feitos e a superioridade espanhola. Conforme Buarque salienta, "Nesses poemas [Rusticatio Mexicana e La Araucana] há vestígios de americanismo, descrições, evocações, assombro lírico [...]". Mas complementa e arremata: "Eram, entretanto, $[. .$.$] produto de um esforço ingente da raça conquistadora. \mathrm{O}$ americanismo não passou daí”. (HOLANDA, 1996: 36).

A estrofe abaixo do poema de La Araucana testifica a visão que os espanhóis tiveram ante as virtudes indígenas, contudo tais qualidades são prontamente menosprezadas quando comparadas à dos colonizadores.

Los índios Promaucaes és una gente

Que está cien millas antes del estado

Brava, soberbia, prospera y valiente

Que bien los españoles la han probado:

Pero com quanto digo, es diferente

De la fiera nación, que, cotejado

El valor de las armas y excelência,

Es grande la ventaja y diferencia (ERCILLA, 2003: s/p). 
Em La Araucana, a intenção do poeta e soldado Ercilla não era enaltecer os indígenas e a natureza americana, mas sim narrar o sucesso da batalha empreendida pelos espanhóis no Chile contra os araucanos sublevados. Contudo, mesmo que o objetivo primeiro do poeta não fosse o elogio a terra; a natureza latino-americana fora destacada e aí sim, encontramos então, tênues vestígios de americanismo.

Que aquel sítio cercado de montaña

Que é um bajo e recogido lhano,

De acéquias copiosísimas se banã,

Por zanjas con industria hechas a mano,

Rotas al nacimiento, la campanã,

Se hacen en breve un lago y gran pântano [...] (ERCILLA, 2003: s/p)

Buarque, afirma que poemas de "tendências americanistas" como Rusticatio mexicana e La Araucana foram produzidos num momento de violento choque cultural e militar entre duas civilizações desenvolvidas, “[...] onde o estado de adiantamento e a cultura social destes era relativamente elevado". (HOLANDA, 1996: 36). Sendo assim, a grandeza cultural/militar indígena e a natureza americana são evidenciadas e mesmo que não seja a intenção primeira dos poetas, causa assombro e admiração nos espanhóis.

Comparando tais poemas aos que na América portuguesa foram produzidos, Buarque salientou que "No Brasil o espetáculo divergiu bastante", o índio foi esquecido pelos colonizadores e a natureza não despertou nenhum "assombro lírico".

[O espanhol não] aspira confundir-se com a terra pródiga, num delírio panteísta. Isso na América Espanhola. No Brasil, o espetáculo divergiu bastante. $\mathrm{O}$ povo português menos idealista e, se quiserem, mais prático que o espanhol, não teve uma impressão tão sútil da natureza como aquele. Além disso, as tribos selvagens e erradias que aqui habitavam não poderiam inspirar, aos dominadores, em geral incultos e rudes, senão desprezo e ódio. (HOLANDA, 1996: 37, grifo nosso).

Nesta passagem, Buarque fez sua primeira comparação entre América Espanhola e Portuguesa, destacando a visão do espanhol e do português ante o paraíso: a América. Em Originalidade Literária Buarque compara o idealismo espanhol perceptível em La Araucana e Rusticatio Mexicana à despreocupação dos portugueses para com a nova 
terra, há assim um esboço comparativo entre tipos que seriam caros ao autor: o semeador e o ladrilhador ${ }^{11}$.

Em La Araucana e Rusticatio Mexicana a perspectiva idealista do espanhol transparece quando este se assombra ante as árvores frondosas, à fauna exuberante, à inocência/bravura/nudez indígena. Imagens paradisíacas que podem ter levado o espanhol a relacioná-las ao Éden, considerando a mentalidade religiosa da época . Por sua vez a ação racional do ladrilhador é evidenciada quando ante de tudo aquilo lhe era diferente, este não se “[...] confundi[u]com a terra pródiga, num delírio panteísta." (HOLANDA, 1996: 37). O espanhol idealizou um futuro para sua nova terra, contudo não se confundiu com ela, conforme os portugueses ${ }^{12}$, mas antes a ela sobrepôs, a modificou, a colonizou. Interiorizou-se, instituiu leis rígidas, planejou metodicamente cidades e mediante o labor indígena, as edificou ${ }^{13}$. "Na maior parte dos domínios que possuía na América, o espanhol não se identificou a tal ponto com a terra e a gente da terra, antes superpôs-se a uma e a outra" (HOLANDA, 1936: 27).

Em contraposição, conforme Buarque salienta, se nestes poemas há assombro lírico ante a grandiosidade da natureza e da bravura indígena, aqui a situação foi bem diferente: "O povo português menos idealista e, se quiserem, mais prático que o espanhol, não teve uma impressão tão sútil da natureza como aquele" (HOLANDA, 1996: 37, grifo nosso). Há neste trecho uma um comparativismo que opõe idealismo espanhol à praticidade portuguesa.

O termo "praticidade" em Buarque em nada tem a ver com habilidade de fazer algo muito bem, mas sim, relaciona-se ao modo como o português agiu e modificou o ambiente. Essa modificação processava-se com o mínimo de planejamento e de esforço, mas com muito desleixo, improviso, liberalidade e vontade de enriquecer rapidamente.

\footnotetext{
${ }^{11}$ O Semeador e o Ladrilhador é o título do quarto capítulo de Raízes do Brasil, apesar de a primeira edição ter como título passado agrário (continuação), o comparativismo entre espanhóis -metódicos - e portugueses - desleixados - já é patente na edição princeps. O fato é que na segunda edição de Raízes, Buarque dá nome aos tipos, caracterizando o espanhol como ladrilhador e o português como semeador, além disso, insere a nota Natureza e Arte. Conforme a nota, podemos concluir que os termos foram retirados por Buarque do Sermão da Sexagésima (1655), proferido por padre Antônio Vieira.

${ }^{12}$ Segundo Buarque os portugueses confundiam-se com a terra de diversas formas: a) suas cidades não se sobrepunham à natureza, não a modificava, b) aclimatavam-se bem a gente e aos costumes, não possuíam orgulhos de raça, se misturavam, dormiam em redes, se lhe faltava-lhe o pão, comia o que a terra lhe proporcionava e c) o português não impôs nenhuma lei rígida à colônia, as relações transcorriam por meio de uma liberalidade, sancionada pela Coroa. Calderón apresentou a mesma visão que Buarque quanto à flexibilidade portuguesa no que toca à frouxidão das instituições. "La colonización portuguesa en Brasil, fue menos rígida, el aislamiento comercial menos estrecho y la religión menos fanática y omnipotente como en las colônias españolas”. (CALDERÓN, 1979: 22).

${ }^{13}$ Como ladrilhador, o colonizador espanhol antecipava mentalmente suas construções, planejava, contudo era também personalista, logo enxerga o trabalho mecânico como algo pouco nobilitante, restava ao indígena, ou no caso do Brasil ao negro, ser os pés e as mãos de seus senhores.
} 
O portugueses "[...] deixaram que a colonização se fizesse por si, de acordo com seu espírito imprevidente e eminentemente prático.” (MONTEIRO, 199: 166), com toda sua "praticidade", não colonizaram o Brasil, mas sim o feitorizaram.

A "praticidade" lusa seria evidenciada na incessante busca por riqueza fácil. $\mathrm{O}$ ideal do aventureiro seria sempre "[...] colher o fruto sem plantar a árvore. Esse tipo humano ignora fronteiras [...] onde quer que se erija um obstáculo a seus propósitos ambiciosos, sabe transformar esse obstáculo em trampolim". (HOLANDA, 1936: 21). De acordo com Vitor A. Pompermayer (2017) "Seguindo o pensamento buarqueano, do espírito aventureiro se chega ao que ele chama de semeador [...]" (POMPERMAYER, 2017: 8). O tipo aventureiro estaria estritamente ligado ao tipo semeador, a vontade de enriquecer sem esforço a saltos largos se materializava no maneira desleixada como os portugueses se propuseram a explorar sua colônia, feitorizando, não colonizando. "[...] a obra dos portugueses no Brasil teve um caráter acentuado de feitorização, muito mais do que de colonização". (HOLANDA, 1936: 80).

Colonizar pressupõe investimentos, demanda tempo, esforço e capital. Feitorizar pressupõe “colher sem plantar", não há método, não há trabalho duro, apenas improviso e a vontade de usufruir de bens da terra sem esforço algum e o mais rápido possível. Portanto, a ordem que o português aceita “[...] não é a que compõe os homens com trabalho, mas a que fazem com desleixo e certa liberalidade: a ordem do semeador, não a do ladrilhador". (HOLANDA, 2016: 202, grifo nosso).

Segundo Buarque a feitorização do Brasil só se tornou possível graças à “praticidade portuguesa", e para tanto mobiliza as categorias de plasticidade e de realismo intentando demonstrar que apesar de tudo, a obra portuguesa no Brasil foi bem sucedida. A primeira categoria é característica típica do aventureiro, a segunda do semeador, tipos que como vimos se relacionam.

Segundo Pedro Meira “A plasticidade dos portugueses desponta na maneira pela qual souberam adaptar-se, recriando alguns de seus costumes com base na matéria existente no local, ou mesmo tomando aos índios algumas soluções de sobrevivência (MONTEIRO, 199: 160). Se o espanhol "não se identificou a tal ponto com a terra", mas a ela se sobrepôs, o português, como era "bem típico de sua extraordinária plasticidade social" (HOLANDA, 1936: 27), amoldou-se a terra - comia o pão da terra, dormia em redes - e a sua gente, a ausência de orgulho de raça é caso exemplar de tal plasticidade. "Ao contrário do que sucedeu com os holandeses, o português entrou em contato íntimo com a população de cor. [...] ele cedia com docilidade ao prestígio 
comunicativo dos costumes [...]. Americanizava-se ou africanizava-se, conforme fosse preciso". (HOLANDA, 1936: 38)

Em relação ao realismo luso, a discussão se torna central em Visão do Paraíso, mas já é patente na segunda edição de Raízes (1948). Conforme Buarque a larga experiência lusitana no contato com outros povos teria entorpecido a sua "sensibilidade para o exótico".

O gosto da maravilha e do mistério [...] ocupa espaço singularmente reduzido nos escritos quinhentistas portugueses sobre o Novo Mundo. [...] Ou porque a longa prática das navegações do Mar Oceano e o assíduo trato das terras e gentes estranhas já tivessem amortecido neles a sensibilidade para o exótico, ou porque o fascínio do Oriente ainda absorvesse em demasia os seus cuidados sem deixar margem a maiores surpresas, a verdade é que não os inquietam, aqui, os extraordinários portentos, nem a esperança deles. (HOLANDA, 1994: 1).

Na edição de 1948 o autor de Raízes salienta que Portugal realizou sua unidade política no século XIII, antes de qualquer outro Estado europeu, e libertou-se precocemente dos sarracenos, alcançando homogeneidade étnica. Sendo assim, não foi necessário submeter-se a um mundo ordenado, sujeitando-se “[...] a leis rígidas, ditadas por motivos superiores às contingências humanas" (HOLANDA, 2016: 204-205) conforme os espanhóis. Para o autor, a unidade prematura teria gerado uma "satisfação precoce", obstando ações que requeressem congregação de energias que modificassem a realidade. Renunciaram assim ao idealismo e aos códigos formais tão prezados pelos espanhóis, manifestando um "natural conservantismo", o tão habitual "deixa estar" luso. Logo, onde a realidade não desperta o devido interesse e satisfaz o pensamento, para quê ter trabalho de modificá-la? Improvisa-se, amoldando-se ao ambiente, comendo o pão da terra, dormindo em redes e espreguiçando-se na geografia.

O navegador/colonizador português realista como é, não teve "impressão tão sútil da natureza" (HOLANDA, 1996: 37), nada o surpreendia, mas tudo o satisfazia, por isso se adapta a terra e quando fazia algo para modifica-la, era "prático", fazia o mínimo, com desleixo, improviso e liberalidade, mesmo porque a intenção na terra pródiga era alcançar a "boa fortuna" a saltos largos. Logo, contrapondo-se ao colonizador espanhol, o colonizador português “[...] se prende antes a um realismo 
fundamental, que renuncia a transfigurar a realidade por meio de imaginações delirantes ou códigos de posturas e regras formais [...]" (HOLANDA, 2016: 195). A feitorização condizia bem com o aventureiro e com semeador.

A semeadura e a ausência da ética do trabalho entre os portugueses seriam destacadas pelo autor na "praticidade" do colonizador lusitano ao semear as cidades irregulares, na preferência pelo litoral, na liberalidade da corte e na manipulação dos tupis para atingir fins próprios, para tanto fundamentaria tais análises em fontes como as Ordenanzas de descubrimiento nuevo e poblacion de las Indias (1573), no Regimento de Tomé de Souza (1548), e na Carta de Tomé de Souza (1553).

Contrastando as cidades hispano-americanas metodicamente planejadas pelo ladrilhador com a agenda colonizadora lusa implementada pelo semeador no Brasil, Buarque conclui que o desleixo aqui imperou, sendo assim: “As casas eram semeadas com desalinho, em volta de uma igreja toda branca [...] (HOLANDA, 1936: 62, grifo nosso). A semeadura transfigurada nas edificações desalinhadas portuguesas fica patente e é fundamentada por Buarque mediante a análise da Carta de Tomé de Souza. Conforme prescrições do Regimento de Tomé de Souza, uma das primeiras missões do governador geral seria cercar as povoações para defender os colonos dos levantamentos indígenas. Em resposta à solicitação real, Tomé de Souza notifica a D. João III quanto à impossibilidade de cercar os povoamentos dado à desordem e à distância das construções: “[...] Estas duas villas de São Vicente e Santos não estão cercadas e as casas de maneira espalhadas que se não podem cercar [...] é tudo feito em deshordem [...] (SOUZA apud Holanda, 1936: 62).

No que se refere aos locais para a edificação dos centros urbanos, fundamentando-se nas Ordenanzas Espanholas, Buarque salienta que para os espanhóis - contrariando as facilidades de comunicação e de comércio proporcionada pela costa Atlântica - a preferência pelo interior era notória, e relacionava-se com a maior comodidade dos colonos, seja devido ao clima mais ameno e, portanto, semelhante ao da mãe pátria, seja pela segurança, contra as invasões piratas. Buarque afirmou, em Raízes do Brasil, que os legisladores espanhóis orientavam os colonos a não estabelecerem sítios de povoação no litoral, “[...] devido ao perigo que há neles de corsários, por não ser sadio, e porque a gente desses lugares não se aplica em lavrar ou cultivar a terra, nem se formam tão bem em costume" (HOLANDA, 1936: 68-69). 
No se elijan sitios para pueblos en lugares maritimos por el peligro que en ellos ay de cossarios y por no ser tan sanos y porque no se da en ellos la gente a labrar y cultivar la tierra ni se forma en ellos tan bien las costumbres sino fuere adonde ouiere algunos buenos y principales puertos y destos solamente se pueblen los que furen necesarios para la entrada, comerçio y defensa de la tierra. (FELIPE II, 1841: 106)

Prescrições que por sua vez, diferenciavam-se bastante do que era estabelecido no Regimento de Tomé de Souza. Este interditava qualquer pessoa de ir terra adentro sem a permissão do governador-geral, provedor-mor ou capitão donatário, a desobediência era passível de multas. "Pela terra firme adentro não poderá ir tratar pessoa alguma sem licença vossa [...] sob pena de ser açoitado sendo pião e sendo de maior qualidade pagará vinte cruzados [...] (DOM JOÃO III, 1548: 5). Logo, em contraposição às Ordenanzas Espanholas que desaprovam os assentamentos na costa Atlântica, os portugueses, com toda a sua "praticidade" instalaram-se preferencialmente no litoral, para evitar gastos e favorecer o envio de mercadorias para Portugal.

Quanto à displicência da corte portuguesa pela administração de sua colônia, Buarque fundamenta-se tanto no Regimento quanto na Carta de Tomé de Souza encaminhada ao rei português. Em ambos os documentos observa-se a transplantação das obrigações do Estado para os donatários ${ }^{14}$. Em relação à segurança, os capitães donatários, sesmeiros e colonos foram obrigados a se armarem, caso contrário, seriam multados. "Cada Capitão em sua Capitania, será obrigado a ter ao menos dous falcões e seis berços [...] e achando-se que as não têm, pagarão em dobro a valia das armas [...]" (D. JOÂO III, 1548: 6). O sistema jurídico também seguia o mesmo ritmo de displicência, se valendo basicamente de delações. "Transpassar de uma captania para outra sem permissão pena de cinqüenta cruzados, a metade para os cativos e a outra para quem o acusar”. (D. JOÃO III, 1548: 8). Quanto à economia, o estabelecimento de preços ficava a cargo dos capitães donatários ${ }^{15}$. "Hei por bem que com os ditos Capitães e Oficiais assenteis os preços que vos parecer que honestamente podem valer as mercadorias que na terra houver". (D. JOÃO III, 1548: 5)

\footnotetext{
14 Mesmo com a implantação do governo-geral é notório que a segurança, a justiça, e a fazenda permaneceram de certa forma sob a jurisdição dos capitães, ainda que em alguns casos não a quisessem. ${ }^{15}$ A coroa apenas interferia se as atitudes dos colonos comprometessem sua política de lucro fácil e rápido, por isso é reticente quanto às distorções dos preços do pau-brasil e à importação de produtos de outros locais, senão de Portugal.
} 
Portanto no que toca à liberalidade da corte portuguesa, a semeadura se fez presente mediante os métodos de colonização postos em prática, estes teriam deslocado a autoridade do Estado para os capitães donatários. Devido ao desleixo da corte, multiplicava-se o número de pessoas favorecidas pela ausência de um poder centralizado e eficaz. Conforme Sérgio Buarque aponta: "Os elementos anárquicos sempre frutificaram aqui, com a cumplicidade ou a indolência displicente das instituições e costumes." (HOLANDA, 1936: 6).

$\mathrm{Na}$ relação com os indígenas, os portugueses também seguiram o mesmo ritmo de desleixo e de "praticidade". Não se deslumbram ante os tupis, mas encontraram funcionalidade no convívio. Conforme o autor, quando os portugueses aportaram no Brasil, os tupis-guaranis já haviam se estabelecido no litoral. Sendo assim, de Norte a Sul se falava o mesmo idioma, fato que teria facilitado a dominação. "É significativo que a colonização portuguesa não se tenha firmado ou prosperado muito fora das regiões povoados dos indígenas da língua geral. [Tupis] Estes, dir-se-ia que prepararam apenas o terreno para a conquista lusitana". (HOLANDA, 1936: 78)

Onde a expansão dos tupis sofria um hiato, como nas capitanias do Espírito Santo, Ilhéus e Porto Seguro, o jeito era promover migrações de tupiniquins para deflagrar as tribos rivais e assentar povoados, firmando a posse portuguesa. "Como já foi dito, não importava muito aos colonizadores povoar e conhecer mais que as terras marginais do Atlântico, onde a comunicação com o reino fosse mais fácil. Assim, o fato de acharem essas terras habitadas de uma só raça de homens, falando a mesma língua, não podia deixar de representar uma inestimável vantagem". (HOLANDA, 1936: 79)

Logo, o espanhol/ladrilhador não "aspira confundir-se com a terra pródiga, num delírio panteísta" (HOLANDA, 1996: 37) e por isso planeja e constrói. Já "O povo português [...] mais prático que o espanhol não teve uma impressão tão sútil da natureza como aquele. [...] as tribos selvagens e erradias que aqui habitavam não poderiam inspirar, [...] senão desprezo e ódio" (HOLANDA, 1996: 37), logo, procurou usufruir da terra e de sua gente, feitorizou, semeou cidades irregulares, delegou responsabilidades, numa "praticidade", sempre buscando riqueza fácil. Há assim na análise sobre o idealismo espanhol e a praticidade portuguesa desenvolvida em Raízes uma discussão comparativa que já apareceria, obviamente bem menos elaborada, no primeiro artigo de Buarque.

Prosseguindo na análise da obra do autor peruano, observamos que $L a$ originalidad intelectual de América objetivava levantar os fatores de originalidade 
literária da América, enfatizando obras e autores - inclusive brasileiros - que muito contribuíram para a emancipação intelectual latino-americana.

Calderón teceu elogios a Gonçalves Dias, e o elegeu "el iniciador de una literatura nacional americana" este se destacava não só por narrar as belezas naturais, mas também por evocar a vida indígena. Os poemas de Dias se contrapunha aos de diversos poetas que "[...] se inspiran[vam] en el paisaje y ovidan al indígena moldeado por la tierra". El lírico brasileño une ambos cultos de la tierra pródiga y del hombre cobrizo" (CALDERÓN, 1919: 63-64)

\footnotetext{
Nosso céo tem mais estrellas,

Nossas varzeas tem mais flores,

Nossos bosques tem mais vida,

Nossa vida mais amores

$[\ldots]$
}

Es o poeta épico de los indígenas, de los tymbiras 'esbeltos como el tronco de la palmera, flexibles como la flecha bien tallada' (DIAS apud CALDERÓN, 1919: 64)

Para Buarque o "homem americano" apareceria primeiramente nas obras de José Basílio da Gama $^{16}$ (1741-1795) e Santa Rita Durão ${ }^{17}$ (1722-1784), o indianismo inauguraria o americanismo à la brasileira. “[...] o indianismo representa o primeiro tatame feito entre nós para a criação de uma literatura nacional. A primeira fase do indianismo, no Brasil não passou de Basílio da Gama e Durão” (HOLANDA, 1996: 38). Com a publicação dos Primeiros Cantos em 1846, Gonçalves Dias inauguraria “a segunda fase do americanismo com o romantismo indianista" (HOLANDA, 1996: 39).

Fazendo ponderações aos elogios tecidos por Calderón ao indianismo de Dias, Buarque, influenciado por Romero e Veríssimo, salienta que o indianismo como representação étnica no Brasil é no mínimo problemática. Obras como as de Domingos Magalhaes, A Confederação dos Tamoios é falsa e incompleta "falso, porque é inexata a

\footnotetext{
${ }^{16}$ Poeta brasileiro, autor do poema épico Uruguai (1769). Obra-prima que tem como tema a luta de portugueses e espanhóis contra os índios de Sete Povos das Missões. Os indígenas - instalados nas missões jesuítas do atual Rio Grande do Sul - eram insubmissos às decisões do Tratado de Madri que delimitava as fronteiras do sul do Brasil.

${ }^{17}$ Poeta e religioso brasileiro. Foi um dos grandes representantes da poesia épica brasileira na época da colonização. Escreveu o poema Caramuru (1781). A obra tem como tema central as aventuras de Diogo Álvares Correia, o "Caramuru" -"filho do trovão" - apelido que segundo o poeta, os índios tupinambás deram ao náufrago português quando o viram usar a arma de fogo. O poema Caramuru retrata o descobrimento do Brasil nos primeiros momentos da chegada dos colonizadores.
} 
pintura dos caracteres selvagens, incompleta porque falta o elemento negro" (ROMERO apud HOLANDA: 40). E obras como as de Gonçalves Dias ${ }^{18}$ (1823-1864) poetizam uma "raça que cuja vida não tem poesia, exagerando sobremodo suas qualidades e atenuando seus defeitos" (HOLANDA, 1996: 40).

De acordo com Buarque, apesar da incompletude e das obliterações o indianismo ofereceu um caráter americano à literatura, se tornando útil ao afastar-nos da imitação ${ }^{19}$ portuguesa. "A existência então em Portugal, da famosa tríade romântica dos Garret, Herculano e Castilho teria levado fatalmente os nossos escritores a imitar o romantismo lusitano, se o indianismo não os tivesse levado a veredas mais amplas e mais nacionais" (HOLANDA: 1996: 41).

Segundo João Kennedy, essa forma de analisar o caráter positivo ou negativo do romantismo indianista, destacando as várias vozes dissidentes para depois mesclá-las, é um ponto importante da obra. Originalidade Literária oferece indícios de um método de escrita que foi caro e muito utilizado em Raízes do Brasil: a do contraponto.

O artigo está organizado na forma do contraponto, recurso conhecido dos músicos antigos e que atingiu o auge com Bach. No contraponto as vozes se alternam, se chocam e se mesclam, compondo um todo mais rico que as simples vozes isoladas. O contraponto abrange as várias vozes, incorpora as dissonâncias e mantém a tensão. Esse recurso será novamente utilizado por Sérgio Buarque, de forma admirável, em Raízes do Brasil. (KENNEDY, 2013: 125-126)

De acordo com Kennedy, em Originalidade Literária Buarque toma como referência dois autores: Silvio Romero e José Veríssimo, acrescentamos como uma terceira referência Calderón, posto que Ideas y Impresiones é utilizada como fonte de fundamentação para suas ideias, bem como de diálogo entre os outros dois autores. Sendo assim, Buarque acolhe as ideias de Calderón sobre o romantismo indianista e sua

\footnotetext{
${ }^{18}$ Poeta, professor, jornalista e teatrólogo brasileiro. Um dos maiores representantes do romantismo de temática indígena. Entre os principais poemas indianistas destacam-se: Marabá, O Canto do Piaga, Leito de Folhas Verdes e "I-Juca Pirama" - considerado o mais perfeito poema épico indianista da literatura brasileira.

${ }^{19}$ Em Originalidad Intelectual de América Calderón também crítica à cópia as ideias estrangeiras, dado que a imitação obstava o objetivo a ser conquistado: a originalidade. Sendo assim, apresenta uma perspectiva promissora quanto seu alcance no futuro "Depués de la fervorosa edad de las imitaciones surgira la producción autônoma” (CALDERÓN, 1919: 73).
} 
importância para a formação de uma identidade nacional brasileira, mas pondera tal argumentação, utilizando as considerações de Silvio Romero e de Veríssimo.

Em Calderón, a busca pela identidade brasileira é exaltada e exemplo a ser seguido pelos demais países sul americanos. No que diz respeito à exaltação da natureza, Buarque se contrapõe afirmando que "Essas ideias desconchavadas foram se infiltrando de tal forma no espírito do povo que os primeiros frutos de nossa literatura nada mais eram que um elogio burlesco e exagerado a nossas riquezas naturais" (HOLANDA: 1996: 38).

No que se refere à exaltação dos caracteres indígenas, Buarque, influenciado por Veríssimo, salienta que "O propósito é sentimentalista, e quiçá patriótico, porém falso. José Veríssimo considera errôneo na inspiração, [...]” (HOLANDA, 1996: 40). As qualidades indígenas foram superestimadas e seus defeitos atenuados.

Como representação étnica criada por alguns autores românticos, o indianismo é questionável. Buarque, influenciado por Romero, afirma que a imagem indígena vulgarizada pelo movimento era a de "portugueses de classe média com cores de selvagem" (HOLANDA, 1996: 40) e que o romantismo ao exaltar o indígena, esqueciase que a grande parcela da população era formada por descendentes de africanos. A marginalidade que foi reservada ao negro "impossibilitava de pensar o Brasil como um todo” (ROMERO apud ORTIZ, 1994: 37). Apesar das argumentações contrárias ao romantismo, imediatamente após a tais considerações negativas, faz ponderações utilizando ambos os autores para validar o romantismo indianista como primeiro movimento de inspiração nacional. Em relação à Veríssimo afirma:

[...] [ o romantismo indianista] porém [foi] fecundo no estímulo literário de nos dá uma anciandade heroica, e gloriosa a nosso próprio torrão, exaltar o índio e fazer-nos adotá-lo como nosso antepassado. Por isso, os primeiros frutos de nosso Romantismo, pela feição indianista que tomaram, constituem na opinião do notável crítico 'o mais importante momento de nossa literatura'. O seu grande merecimento foi o caráter americano, foi a inspiração nacional que o distinguiam. (HOLANDA, 1936: 40)

Em relação a Romero as ponderações surgem na seguinte passagem: “O próprio Silvio Romero, a despeito das contumélias que frequentemente dirigia ao romantismo, 
não deixou de afirmar ter sido útil a nossa literatura. A vantagem de ter nos afastado da imitação portuguesa, era para ele inestimável" (HOLANDA, 1936: 41).

Sendo assim, em guisa de conclusão, Buarque retoma as ideias de Calderón, imprimindo ao romantismo indianista uma visão positiva. A conclusão esperançosa que dá ao seu artigo e que por sua vez, assemelha-se bastante com a do autor peruano, atesta a validação de ambos ao movimento romântico. Mesmo porque, "Se a autenticidade amadurece aos poucos, há que acolher as tentativas feitas para atingi-la" (KENNEDY: 2013: 125). O romantismo indianista era o primeiro passo se para alcançar a tão sonhada originalidade.

O Brasil há de ter uma literatura nacional, há de atingir, mais cedo, ou mais tarde, a originalidade literária. A inspiração em assuntos nacionais, o respeito das nossas tradições e a submissão às vozes profundas das raças acelerarão esse resultado final. (HOLANDA, 1996: 41).

Por la continuidad de la inspiración, por el respeto de tradiciones que ya son seculares, por la sumisión à las voces profundas de la raza, por la exaltación de los heroes y de los fastos de la tierra materna, serán originales el arte y la filosofia de Ultramar [...] (CALDERÓN, 1919: 80)

\title{
2. La originalidad Intelectual de América (1919): A originalidade encontrada nas tradições ibéricas
}

\author{
¿Son los iberoamericanos de raza latina?
} Francisco García Calderón

Apesar do destaque que Buarque dá ao indianismo em Originalidade Literária, penso que a busca de uma originalidade que partisse da inspiração indianista, em Buarque e em Calderón, tinha as suas limitações. Nesta prematura tentativa de formação do sentimento nacional, o índio foi cantado por espanhóis, as vozes ibéricas falavam dele e por ele. "En el Brasil, donde parece más enérgico el sentimiento nacional, ha triunfado el americanismo: se describe la selva ubérrima o se canta al indio vencido por la civilización”. (CALDERÓN, 1919: 78, grifo nosso).

Se o indígena chegou a ser protagonista como elemento representativo da nacionalidade, o era de forma dúbia, tanto que desaparece quase completamente, suplantado pela discussão das tradições ibéricas em Las Democracias (1912). O mesmo 
se poderia dizer em relação a Buarque, se considerarmos Raízes do Brasil. "Nem o contato e a mistura com as raças aborígenes fizeram-nos diferentes dos nossos avós [lusos] como gostaríamos de se-lo.” (HOLANDA, 1936: 15). Em Calderón e Buarque os elementos originais de nossa nacionalidade seriam outros: nossas raízes seriam ibéricas.

Tanto Calderón quanto Buarque retornaram às origens, evidenciando as peculiaridades ibéricas ${ }^{20}$ como elemento formador de identidade nacional, bem como criticaram o seu avesso: a imitação das ideias estrangeiras, identificando nelas, os fatores que impossibilitavam a concretização de sonhada originalidade.

Robert P. Newcomb (2012) relaciona a passagem que conclui Originalidade Literária à Rodó - "O Brasil há de ter uma literatura nacional, há de atingir, mais cedo, ou mais tarde, a originalidade literária. A inspiração em assuntos nacionais, o respeito das nossas tradições e a submissão às vozes profundas das raças acelerarão esse resultado final", - assim como Guilherme Pacheco Pinnheiro (2016) encontra nesta citação a marca da presença de Sílvio Romero, exposta na seguinte passagem:

O gênio deste país, ainda vago e indeterminado, um dia, ouso esperá-lo, se expandirá aos raios de um forte ideal que o há de fecundar. Andar, porém, estonteado hoje, como sempre, no empenho de nacionalizar a poesia, a literatura, parece-me cousa igual à luta inútil do antigo vidente, do antigo profeta quando buscava furtar-se à ação do Deus que o dominava... O indício nacional há de aparecer, sem que haja necessidade de o procurar adrede; o poeta é antes de tudo homem e homem de um país. Seus sentimentos mais arraigados, as inclinações mais fortes de seu povo hão de forçosamente aparecer. (ROMERO apud PINHEIRO, 2016: 37).

Tentamos demonstrar anteriormente que a passagem que finaliza o artigo Originalidade Literária de Buarque remete à Originalidad Intelectual de América, de Calderón. Contudo é caso digno de se notar que tanto Rodó quanto Romero, assim como diversos outros intelectuais brasileiros/hispano-americanos se lançaram na busca por uma consciência nacional autêntica, contrapondo-se assim a toda forma de valorização das ideias importadas que na visão destes intérpretes, "minavam" a originalidade nacional.

\footnotetext{
${ }^{20}$ Ambos os autores examinam e destacam o culto ao valor pessoal ibérico, discutido em Calderón através do termo El individualismo e em Buarque através do termo personalismo.
} 
O fato interessante no que diz respeito à conclusão que Buarque dá a seu artigo é justamente a ênfase naquilo que ele acredita ser as nossas origens e por isso merecedora de respeito: as tradições de raça. A originalidade, interditada pela cópia das ideias estrangeiras, seria retomada mais rapidamente mediante o "[...] respeito das nossas tradições e a submissão às vozes profundas das raças [...]”. (HOLANDA, 1996: 41). Se em Originalidade Literária Buarque enxerga no romantismo indianista o primeiro passo para a obtenção desta originalidade, em Raízes a autenticidade estaria vinculada às tradições ibéricas, talvez por isso, na primeira edição teceu elogios a uma das principais características ibéricas: o personalismo e à sua capacidade de criar estabilidade política $^{21}$.

Entre nós, já o dissemos, o personalismo é uma noção positiva - talvez a única verdadeiramente positiva que conhecemos. Ao seu lado todos os lemas da democracia liberal são conceitos puramente decorativos, sem raízes profundas na realidade. Isso explica bem como nos países latino-americanos, onde o personalismo - ou mesmo a oligarquia, que é o prolongamento do personalismo no espaço e no tempo - conseguiu abolir as resistências da demagogia liberal, acordando os instintos e os sentimentos mais vivos do povo, tenha assegurado, com isso, uma estabilidade política que de outro modo não teria sido possível. A formação de elites de governantes em torno de personalidades prestigiosas tem sido, ao menos por enquanto, o princípio político mais fecundo em nossa América (HOLANDA, 1936: 52).

É interessante também notar a centralidade que Buarque reservaria a outras características ibéricas, como ao estilo aventureiro do português e a uma particularidade, que apesar de brasileira, originou-se da tradição ibérica: a cordialidade. Penso que para o autor, considerando estritamente a década de 1930, dar ouvidos à cordialidade, ao personalismo, à ética da aventura seria uma forma de resguardar o passado do cosmopolitismo invasor, encontrando nestas peculiaridades ibéricas/brasileiras, qualidades que seriam mais bem aproveitadas, não só por ser bem conhecida pelo brasileiro, mas também vivenciada e reconhecida como parte de si, de suas origens. Portanto, somente nelas seriam encontradas as soluções para os problemas nacionais, valorizando nossas raízes, afastaríamos qualquer imitação, bem

${ }^{21}$ Consideramos aqui a edição de 1936, posteriormente nas demais edições, Buarque defenderá o desmantelamento das tradições ibéricas. 
como faríamos frente às interpretações que nos estigmatizavam. Neste sentido a ética da aventura, para o autor, tinha o seu valor, pois possibilitou que a grande empreitada da colonização fosse profícua, além de evidenciar a grandiosidade do elemento luso, afoito por empreitadas que requeressem coragem. "Na obra da conquista e colonização de novos mundo coube ao espírito de trabalho [...] um papel quase nulo. A época predispunha aos gestos e às façanhas audaciosas, galardoando bem aos homens de grandes voos. (HOLANDA, 1936: 22).

A cordialidade por sua vez, imprimiria aos costumes brasileiros uma sociabilidade restrita, fundamentada em laços pessoais. A busca incessante por uma relação mais íntima, mais próxima, casaria muito bem com o personalismo, onde um líder carismático cumpriria o papel de "pai”, protegendo e disciplinando. Tal relação entre "pai e filhos" era bem quista pelo brasileiro e fora prontamente incorporada pela elite política nacional, apesar de se mostrar incompatível com uma sociedade onde as relações se firmam em interesses que remetem à liberal-democracia.

Em relação a Calderón, a passagem escrita por ele e transcrita por Buarque sobre a "sumisión à las voces profundas de la raza" é esclarecedora. A originalidade seria alcançada quando se valorizasse as tradições de raças. Mas a quais tradições Calderón se referia? Tradições ibéricas ou latinas?

Os historiadores que discutem o pensamento do escritor peruano divergem quanto ao caráter biológico ou cultural que o autor imprimiu em suas obras. Teodore Hampe Martínez (2003), por exemplo, defende o aspecto cultural, afirmando que ao utilizar o termo raça Calderón estaria se referindo aos "[...] elementos de tradición, cultura, lengua religión y identidade colectiva”. (ZEVALLOS apud MARTÍNEZ, 2003: 30).

O próprio Calderón expressaria tal prerrogativa em Las Democracias "La idea de raza, es decir tradiciones y cultura, domina en la política moderna" (CALDERÓN, 1979: 214). Apesar de professar que o termo raza teria um teor cultural, o autor o utiliza de forma indiscriminada. Se retrocedermos em uma obra anterior e mais ampla - Las Democracias - fica patente que determinadas passagens realmente revelam um sentido cultural, mas em diversas outras o termo raza toma um significado claramente biológico. 
Antes de analizar los diversos aspectos de la historia americana, es necesario conocer el gênio de la raza conquistadora." (CALDERÓN, 1979:7). / "En la raza degenerada por el contacto con Africa y los turcos, [...]". (CALDERÓN, 1979: 7-8)/ “[...] los hijos nacidos de la unión de negro con zambo o indígena son generalmente inferiores a sus padres, mental y fisícamente. (CALDERÓN, 1979: 197)/ "No basta un solo cruzamiento para que los caracteres de la raza superior sean comunicados al mestizo en forma duradera. Son necesarias uniones de tercer, cuarto y quinto grado, es decir, tantos cruzamientos sucesivos entre un padre o madre de raza blanca para el mestizo esté en condiciones de asimilar la cultura europea [...] (CALDERÓN, 1979: 200, grifo nosso)

Sendo assim, creio que Calderón utiliza o termo raza num sentido biológico referindo-se às características psicológicas ibéricas, indígenas e negras, assim como utiliza o mesmo termo para referir-se a aspectos culturais - língua, religião, ideias políticas - provenientes da França e da Itália, ou seja, latinos. E se fizermos um balanço do seu discurso sobre a tradição ibérica e latina o que transparece em suas obras é a preponderância da primeira sobre a segunda.

El Individualismo ${ }^{22}$ (culto ao valor pessoal) seria o principal traço inato do elemento ibérico. "El individualismo es la nota fundamental de la psicología española. Rasgo ibérico, tiene la fuerza de un imperioso atavismo" (CALDERÓN, 1979: 8). Traço biológico chave para se compreender a política caudilhesca ibero-americana, bem como sua repercussão positiva, na visão do autor, para a implantação dos ideais democráticos na América Latina. Relacionar tais traços à ação de determinados caudilhos (Rosas, Pedro II, Blanco, Melgarejo...) que “democratizaram a América” era justamente o objetivo primeiro do livro. A centralidade que Calderón reserva ao individualismo ${ }^{23}$ é

\footnotetext{
${ }^{22}$ Já para Buarque o culto ao valor pessoal estaria ligado a aspectos históricos: as grandes navegações. Ou seja, o heroísmo requerido para se lançarem aos mares desconhecidos teria desenvolvido nos portugueses e espanhóis o gosto pela aventura, bem como teria contribuído para fomentar um sentimento de valorização àqueles homens que se destacavam pela coragem, pelo bastar em si próprio.

${ }^{23}$ Apesar de Calderón dizer que o individualismo é um traço psicológico da raça ibérica, remetendo assim, a uma herança biológica, em determinados momentos o individualismo é tratado como uma caraterística fomentada pelas lutas peninsulares. Estas promoveriam o surgimento de uma mentalidade de exaltação aos grandes heróis e aos feitos individuais. Nesta perspectiva o individualismo se relaciona mais a fatores históricos do que biológicos. Em outros momentos Calderón refere-se a um individualismo modificado pela cultura romana, no qual as formas coletivistas e anárquicas espanholas foram substituídas por um sistema político/cultural que reforçava o poder do pater familie sobre a família ibérica. Sob esta perspectiva o individualismo teria suas feições biológicas depuradas pela cultura latina. Por fim sustenta a importância do individualismo para a política ibero-americana, alertando para o perigo de sua degeneração ante "ao fanatismo africano", - aqui se observa uma forte atenção às questões
} 
indício da relevância que dá ao aspecto biológico em sua obra, assim como a citação a diversos autores que se destacaram por uma interpretação biologizante da sociedade Gustave Le Bon, Chales Henry Pearson e Carlos Octávio Bunge - testifica suas predileções.

Por sua vez, quando Calderón utiliza a expressão "suicídio de raça", na passagem abaixo, creio eu que o autor peruano não esteja se referindo a um aspecto biológico - a mestiçagem com intuito de branqueamento, por exemplo, - mas sim que esteja se referindo aos perigos que a assimilação cultural/econômica indiscriminada dos princípios neo-saxões poderiam ocasionar aos ibero-americanos. Por isso elogia a hostilidade latina quando em contato com os ianques.

El contacto de la civilización anglosajona podrá renovarlo parcialmente, pero la transformación integral del genio propio de nuestras naciones no se operará nunca. Ello significaría el suicidio de la raza. Allí donde los yanquis y los latinoamericanos se ponen en contacto, se observan mejor las contradicciones insolubles que separan a los unos de los otros. Los anglosajones conquistan la América comercialmente, económicamente, imponiéndose a los latinos, pero la tradición y el ideal, el alma de estas repúblicas les son hostiles. (CALDERÓN, 1979: 157)

Sendo assim, penso que em Calderón a cultura latina é pensada como algo distinta, mas complementar à raça ibérica. Apesar de não nos atentarmos para tal distinção, dado que no decorrer das grandes navegações e descobertas, tanto os espanhóis quanto os portugueses já se encontravam latinizados há tempos pelas invasões romanas, o autor peruano por seu turno, demarca bem a diferença entre ambas. Ou seja, para Calderón, na América, a raça era a ibérica/negra/indígena, a cultura que melhor a ela se adaptou, era a latina.

Cierto que hablando de raza no podríamos afirmar que las repúblicas americanas son naciones latinas. Serían más bien indo-africanas o afroibéricas. La cultura latina —ideas y arte de Francia, leyes de Roma, el catolicismo- originó en Sudamérica una forma de pensar análoga a la de

biológicas - e ante ao protestantismo, análise que descamba para a problemática da absorção de elementos culturais exógenos. 
los grandes pueblos mediterráneos, hostil o extraña a la civilización germânica o la sajona (CALDERÓN, 1979: 153, grifo nosso)

A breve discussão que aqui me propus sobre o termo raça em Calderón é relevante para se compreender a quais vozes "profundas de la raza" Calderón daria ouvidos. Penso que apesar de ser influenciado por Rodó, para quem a discussão sobre a latinidade é central, em Calderón a defesa da cultura latina é circunstancial. A cultura latina só é relevante na medida em que ela se adapta melhor à raça ibérica e seu apelo é circunscrito aos perigos que imperialismo norte-americano poderia oferecer ao continente.

Por isso, creio que em Calderón a hispanidade toma uma centralidade maior que a latinidade. "Más fuerte todavía que la religión y la lengua, la identidad de raza explica las analogías entre los pueblos americanos y constituye una promessa de unidad duradera. (CALDERÓN, 1979: 186) Tanto o é que em La Creación de un Continente (1913) no capítulo intitulado Panamericanismo e Paniberismo, Calderón elege o paniberismo ${ }^{24}$ como possível substituto ao "interesseiro e fictício pan-americanismo" norte-americano, ou seja, o autor reconhece a necessidade de união e conclama os países ibéricos da península e do continente, inclusive o Brasil para compor uma confederação fraternal baseadas na similitude de raça, em períodos de guerra ou de paz. "El paniberismo es una tendencia de raza. Restaura antiguos vínculos morales oxidados por el tiempo. Congrega a Europa y a las repúblicas de ultramar en una federación ideal" (CALDERÓN, 1979: 239).

A latinidade por sua vez também é requerida por Calderón em sua obra antecessora Las Democracias, contudo seu interesse é circunscrito a um período em que os Estados Unidos impunham medo. Sendo assim, a defesa da latinidade é importante, mas circunstancial, foi utilizada por Calderón com intuito de se defender contra o militarismo cultural e militar norte-americano, tanto o é que, quando o perigo imperialista fosse o japonês, o discurso em prol da latinidade veemente contrária aos anglo-saxões, apesar de ainda presente, é amenizado. "A pesar de esenciales diferencias, los latinos de ultramar tienen lazos comunes con los yanquis, una religión secular, el

\footnotetext{
${ }^{24}$ Conclama o Paniberismo, mas reconhece a dificuldade de sua implantação e a necessidade de superar tais obstáculos. Dentre as interdições para a união entre países ibéricos e a Ibero América estaria a visão preconceituosa dos espanhóis ante os ibero-americanos e a visão de determinados hispano-americanos que viam a aproximação da Espanha como uma nova tentativa de colonização.
} 
cristianismo, una civilización coherente, europea, occidental”. (CALDERÓN, 1979: 181).

Em Espelho de Próspero Richard Morse salienta que os horizontes de Rodó “[...] eram os de Paris no final do século vinte" (MORSE, 1988: 127) e que suas referências foram superficiais, pois negligenciou o contexto cultural espanhol. "(a Espanha não é mencionada sequer uma vez)" (MORSE, 1988: 127). Indo um pouco mais longe, Rodó não cita sequer uma vez o termo ibero ou ibero-americano em Ariel (1900) ${ }^{25}$ e menciona apenas uma vez a palavra Hispano-América. Em Calderón ocorre exatamente o contrário, o autor enfatiza a questão das peculiaridades da tradição/raça ibérica, o contexto de luta peninsular, a necessidade de uma aproximação maior com a Espanha e o exemplo intelectual e ajuda financeira que a América poderia oferecer à Espanha e a Portugal. Se atentarmos para o método de análise de Morse, quando afirma que Rodó não cita sequer uma vez a Espanha, veremos que Calderón em Las Democracias/ La Creación de um continente menciona a palavra Espanha e termos afins - espanhóis, espanhol, espanhola, espanholas - quatrocentos e noventa e oito vezes, enquanto isso, menciona a França e termos a ela relacionados, cento e trinta e duas vezes. Dados que lançam luz sobre o sentido complementar que a cultura latina exerceria sobre a raça ibérica na visão do autor. Quanto ao termo Ibero-América e América latina, ambos são utilizados de forma indiscriminada pelo autor, sem atentar para o teor ideológico dos conceitos, assim com o fizera com o termo raza.

Em posição contrária, Regiane Gouveia salienta que "Embora tenha tido importância em sua obra, a ideia de latinidade prevaleceu sobre a hispanidad devido ao fato de que a França, em sua opinião, alimentava o espírito intelectual das gerações do outro lado do Atlântico”. (GOUVEIA, 2016: 195, grifo nosso).

Sustento, no entanto, que o processo de síntese com a cultura latina patente em Las democracias e La creación de un Continente é sempre pensada no sentido de valorização das tradições ibéricas. Esta valorização das tradições ibéricas se daria, ao meu entender em Calderón, de duas formas: a primeira por meio da absorção de ideias latinas que corrigissem possíveis falhas na índole ibérica, mas sem suplantá-la; a segunda por meio da absorção de ideias francesas que alimentariam "o espírito

\footnotetext{
${ }^{25}$ Rodó desenvolveu uma discussão sobre o termo Ibero-América em El mirador de Próspero (1913). Nele inseriu o Brasil num projeto de identidade supranacional: a Ibero-América, contudo, como Bernardo Ricupero (2016) salienta, suas argumentações foram superficiais, fundamentada nas proposições ambíguas do poeta luso Almeida Garret e circunstanciais, limitadas aos interesses comerciais firmados pelo tratado da Lagoa Mirim e restritas ao discurso de 1909 pronunciado no Rio de janeiro, dado que não levou adiante a análise.
} 
intelectual das gerações do outro lado do Atlântico", mas que, no entanto, se mostrassem compatíveis com a índole ibérica.

O individualismo era uma peculiaridade ibérica, elogiada por Calderón, mas que também tinha os seus atavismos, a indisciplina era uma delas. Para o autor peruano somente o Cesarismo ${ }^{26}$ e o Catolicismo, herança latina de Roma seriam capazes de "corregir los vicios de la raza iberoamericana sin salir del marco de las tradiciones que le son propias". (CALDERÓN, 1979: 156).

Bajo la doble presión del catolicismo y de la legislación romana, América se latiniza. Aprende a respetar las formas y las leyes, a soportar una disciplina tanto en la vida religiosa como en la vida civil. Al agregarse a estas influencias, las ideas francesas preparan primero y gobiernan luego los espíritus americanos desde la época de la Independencia hasta nuestros días. (CALDERÓN, 1979: 155)

A apropriação do Cesarismo Romano é relevante para se compreender a crítica que Calderón reserva aos pequenos caudilhos, como fomentadores de anarquia, e a defesa do Grande Caudilho, o "pater familie" como elemento disciplinador e figura chave para implantação da democracia na América.

O Catolicismo, por sua vez, segundo Calderón, era altamente compatível com o gênio ibérico, indígena e negra, pois satisfazia “[...] la fantasía de los criollos, el temor supersticioso del indio y el materialismo alegre de los negros”. (CALDERÓN, 1979: 21). Além disso, cumpriria também uma tarefa disciplinadora, domesticando as paixões e a moralidade, ao ponto de o próprio Libertador - Simón Bolívar - utilizar o “[...] el catolicismo como instrumento de Gobierno. [...] Era la tiranía paternalista ejerciéndose sobre sentimientos,conducta y pasiones". (CALDERÓN, 1979: 37).

Para Calderón, se o cesarismo e o catolicismo "depurariam" a índole ibérica, disciplinando-a, as demais correntes e ideias latinas, principalmente francesas, deveriam ser muito bem selecionadas antes de serem transmutadas para Ibero-América.

Se analisarmos as críticas que Calderón fez às ideias importadas, veremos que o autor não é contrário a cópias das ideias alheias, contudo faz reservas quanto àquelas que não se adaptariam à índole ibérica. Ou seja, Calderón pensa sempre em primeiro

\footnotetext{
${ }^{26}$ Sistema de governo centrado na autoridade suprema de um chefe militar e na crença em sua capacidade pessoal, à qual são atribuídos traços heroicos.
} 
plano a tradição/raça ibérica. Defende a cultura latina à medida que ela se adaptou melhor às tradições, contudo, tudo aquilo que fosse incondizente com a raça, seja ela francesa ou romana deveria ser preterida. As críticas ao fascismo ${ }^{27}$ e o repúdio ao positivismo em prol do bergsonismo são fortes indícios da preferência de Calderón, balizada pela preocupação com as tradições ibéricas.

Calderón dispensa severas críticas à doutrina positivista tanto em Las democracias Latinas de América quanto em Ideas y Impresiones. Para o autor a implantação do positivismo em terras americanas era perniciosa, posto que, tratava-se de uma doutrina que ressaltava a supremacia do racional, supervalorizava a ideia de progresso ligando-o à aquisição de bens materiais, fomentava o egoísmo, sendo incompatível assim, com a índole idealista ibero-americana. - subjetivista, cordial, contemplativa - "El positivismo establece así um racionalismo limitado y vulgar, una nueva metafísica que otorga a las fórmulas de la ciencia una verdad absoluta y exalta en la vida, el egoísmo, los intereses materiales y la despiadada persecución de la riqueza.a”. (CALDERÓN, 1979: 150)

Apesar da preponderância da corrente positivista na América Latina, uma reação crescia aos poucos entre os intelectuais ibero-americanos. Para Calderón, conjugando a herança espanhola - quixotismo, dignidade cavalheiresca - às teorias idealistas europeias, por exemplo, ao bergsonismo - mais compatível ao nosso temperamento poderíamos alcançar a tão sonhada originalidade, atenuando a força que o positivismo exercia sobre o continente.

O bergsonismo é uma teoria que nega os preceitos positivistas, valorizando a intuição, a vontade, a subjetividade. Segundo Pierre Montebello (2007), para os bergsonistas a ciência era falha e seu enaltecimento levava o ser humano constantemente a uma vida utilitária, prosaica, egoística e infeliz. "El bergsonismo representa la reacción necesaria: estudia los limites de la ciência, el vicio radical del entendimento, la originalidade del espíritu”. (MONTEBELLO, s/a: 236).

Conforme Calderón salientou, a doutrina idealista de Henri Bergson influenciou uma geração de intelectuais hispano-americanos ${ }^{28}$, que retomaram os estudos psicológicos e puseram em dúvida a infalibilidade da ciência. Os bergsonistas

\footnotetext{
${ }^{27}$ Calderón critica o nazismo e o fascismo em Ideas y Impresiones, enfatizando o desprezo que tais doutrinas teriam para com os mestiços. Salienta que se a Alemanha acusa a França de ser formada por povos inferiores, por serem mestiços, imagina o que os germânicos pensariam e fariam com a América se estendessem seu domínio ao continente ultramar.

${ }^{28} \mathrm{Um}$ dos intelectuais mais ativos bergsonistas e por isso, muito elogiado por Calderón, fora o uruguaio Vaz Ferreira.
} 
expuseram assim, as falhas do método científico positivista, quando aplicado como guia para se explicar uma dada realidade. "Si la ciência aplicada al estúdio de la realidad física no alcanza definitiva verdades ¿como extender su acción y sus métodos al obscuro domínio de la vida moral? (CALDERÓN, 1919: 227).

Portanto, embasado no bergsonismo, Calderón salienta que a América Latina, possuía seu valor. A subjetividade, a capacidade de contemplação e o idealismo sul americano nos caracterizavam e eram motivos de orgulho. Logo, as particularidades ibero-americanas deveriam ser expostas ao mundo, e não ser mais motivo de vergonha, nem alvo de discursos pretensiosamente científicos de caráter depreciativo. Conforme Calderón salientou o filósofo Henri Bergson revelou à "Próspero la sutil presencia de Ariel" (CALDERÓN, 1919: 224), ou seja, que idealismo de Ariel (continente americano) tinha o seu valor perante Próspero (Europa) .

Por sua vez, o reconhecimento externo, seria precedido pelo reconhecimento interno, no qual "las voces profundas de la raza" seriam devidamente ouvidas, respeitadas pela população ibero-americana e não mais interditadas pela invasão e imitação de ideias incondizentes com a índole nacional. Sendo assim, penso que a originalidade a que Calderón se referia ao sustentar a necessidade " [da] continuidad de la inspiración, [do]respeto de tradiciones que ya son seculares, [da] sumisión à las voces profundas de la raza, [da] exaltación de los heroes [...]" (CALDERÓN, 1919: 80) dizia respeito à valorização das tradições ibéricas em síntese contínua com determinados aspectos selecionados da cultura latina. "A esta síntesis espiritual España contribuye con su idealismo; Italia con el paganismo [...]; Francia con su educación llena de armonía”. (CALDERÓN, 1979: 156).

Logo, tanto em Calderón quanto em Buarque, ao tratar especificamente do embate entre tradição e modernidade, podemos notar o lugar de destaque que as tradições ibéricas tomaram. Em Calderón tais predileções perpassam toda uma vida, já em Buarque são patentes na primeira edição.

Considerando a afirmação de Ângela de Castro Gomes de que a "saída depende sempre do lugar onde se deseja chegar" (GOMES, 1998: 503), destacamos que na concepção de Buarque a continuidade ou o expurgo da tradição/herança ibérica dependeria do tipo de sociedade vislumbrada. Caso o fim almejado fosse uma sociedade moderna, ou seja democrática e liberal, a cordialidade e o personalismo deveriam ser extirpados, se não a tivéssemos fim, e o destaque fossem as relações pessoais, a continuidade de tais legados tornar-se-iam viáveis. Na década de 1940, os ventos da 
modernidade sopraram mais forte, além da industrialização e da urbanização, a discussão sobre a democracia intensificou-se com o fim da Segunda Guerra mundial e do Estado Novo, fatos que colaboraram para que o autor de Raízes direcionasse suas críticas para a tradição/herança ibérica preconizando sua perda, mediante uma revolução ainda em processo. Os expurgos a autores do pensamento autoritário e as diversas alterações ou atenuações argumentativas efetuadas na edição de 1948 são prova disso, tanto que Nicodemo afirma que as modificações realizadas na segunda e terceira edição “[...] alteram muito de nossa percepção sobre obra.” (NICODEMO: 2014b: 49)

\section{Conclusão}

A América Latina é um espaço de contradições, de lutas sociais, de histórias, de desigualdades econômicas, mas também de interesses comuns. A incessante busca por uma identidade, fomentada desde o pós-independência e almejada por muitos intelectuais no decorrer de sua história, seria um desses lugares comuns. Tal anseio esteve presente nas obras do peruano Francisco García Calderón e do brasileiro Sérgio Buarque de Holanda.

Buarque lera a obra Ideas y Impresiones de Calderón na década de 1920, leitura que daria origem a seu primeiro artigo Originalidade Literária (Correio Paulistano). Sustentamos que o contato com a obra do autor peruano suscitou ressonâncias patentes em sua principal obra: Raízes do Brasil.

A leitura de Ideas y Impresiones ofereceria o andaime discursivo para elaboração dos tipos Semeador e Ladrilhador. Em Originalidade Literária Buarque fez sua primeira comparação entre a América Espanhola e Portuguesa, embasando-se na interpretação desenvolvida por Calderón sobre o idealismo espanhol. Buarque, de posse de tal análise, comparou o idealismo espanhol à praticidade portuguesa.

Outra ressonância seria a importância reservada ao retorno às origens para se melhor compreender o caráter nacional, além da crítica, costumeira para época, às ideias importadas. No mergulho até nossas raízes ambos os autores dariam centralidade à relação entre tradição ibérica e os princípios democráticos. Discussão importante que abre diversas outras possibilidades de análises. 


\section{Fontes}

CALDERÓN, Francisco García (1919). Ideas y Impresiones. Madri: Editorial- América. (1979). Las democracias latinas de América. La creación de un continente. Venezuela: Biblioteca Ayacucho.

HOLANDA, Sergio Buarque de (1996). Originalidade Literária. Correio Paulistano, 22 de abril de 1920. In: ARNONI, Antônio (org.) O Espírito e a Letra. São Paulo: Companhia das Letras. (2 vols.)

(1936). Raízes do Brasil. Rio de Janeiro: Livraria José Olympio.

(1994). Visão do Paraíso: os motivos edênicos no descobrimento e colonização do Brasil. 6 ed. São Paulo: Editora Brasiliense.

\section{Referências bibliográficas}

BRESCIANI, Maria Stella Martins (2004). Identidades Inconclusas no Brasil do século XX - Fundamentos de um lugar-comum. In Memória e (res)sentimento: Indagações sobre uma questão sensível. Brescinai, Naxara (org). 2 ed. Campinas, SP: Unicamp.

CARLOS II, Reconpilacion de los reinos de las Indias. Disponível em: http://www.cervantesvirtual.com/research/recopilacion-de-leyes-de-los-reinos-deindias-mandadas-imprimir-y-publicar-por-la-magestad-catolica-don-carlos-iitomos-2-777027/b808338a-8b0a-40e4-9444-f52ae70a0748.pdf. Acesso em 23 de mar de 2019.

COSTA, Sérgio (2014). O Brasil de Sérgio Buarque de Holanda. Revista Sociedade e Estado - Volume 29 Número 3.

ERCILLA, Alonso de. Disponível em <http://www.biblioteca.org.ar/libros/89803.pdf> Acesso em 10 de fev de 2019.

FELDMAN, Luiz (2016). Clássico por Amadurecimento: Estudos sobre Raízes do Brasil. Rio de Janeiro: Topbooks.

GOMES, Ângela de Castro (1998). A política Brasileira em busca da modernidade: na fronteira entre o público e o privado. In: SCHWARCZ, Lília Mortiz (org.) História da Vida Privada. Vol. 4. São Paulo: Companhia das Letras.

GOUVEIA, Regiane Cristina (2016). América Latina enferma: racismo e positivismo no pensamento político latino-americano em fins do século XIX e início do sécula XX. Tese (Doutorado em História das Ciências e da Saúde) - Fundação Oswaldo Cruz. Casa de Oswaldo Cruz.

KENNEDY, João Eugênio (2013). Um modernista Romeriano: Sérgio Buarque de Holanda. Desenredos. Ano V - número 18.

LANDIVAR, Rafael. $\quad$ Ruscátio. Disponível em <http://recursosbiblio.url.edu.gt/Publi/Libros/2013/RusticatioMX/17.pdf> Acesso em 3 de fev de 2019.

MARTÍNEZ, Teodore Hampe (2003). Francisco García Calderón: América Latina y el Perú del novecentos. Antología de textos. Lima: COFIDE. 
MONTEBELLO, Pierre (2007). Bergsonismo, uma filosofia do futuro, do tempo, da transformação. Revista do Instituto Humanitas Unisinos, Ed. 237.

MONTEIRO, Pedro Meira (1999). A queda do aventureiro: aventura, cordialidade e os novos tempos em Raízes do Brasil. Campinas: Editora da Unicamp. (2009). As raízes do Brasil no espelho de próspero. Novos Estudos, março. .; SCHWARCZ, L. M. (org.) (2016). S. B. Holanda, Raízes do Brasil, ed. crítica, São Paulo: Companhia das Letras.

MORSE, Richard (1988). O espelho de Próspero: Cultura e idéias nas Américas. São Paulo. Companhia das Letras.

NEWCOMB, Robert P (2012). Nossa and Nuestra América: Inter-American Dialogues. Indiana: Purdue University Press West Lafayette.

NICODEMO, Thiago Lima (2014a). Alegoria Moderna: Crítica literária e história da literatura na obra de Sérgio Buarque de Holanda. São Paulo: FAP-Unifesp. (2014b). Os planos de historicidade na interpretação do Brasil de Sérgio Buarque de Holanda. hist. historiogr. Ouro preto. n. 14.

ORTIZ, Renato (1994). Cultura Brasileira e Identidade Nacional. São Paulo: Brasiliense.

PACHECO, Guilherme Pinheiro (2016). A crítica literária de Sérgio Buarque de Holanda entre os anos 1920-1926. (Dissertação - Mestrado) Universidade de São Paulo, Instituto de Estudos Brasileiros.

POMPERMAYER, Vitor Augusto Rocha (2017). Formação do Brasil: um estudo sobre o aventureiro e o semeador sob a luz das análises de Sérgio Buarque de Holanda. XII Congresso Brasileiro de História Econômica \& 13 ${ }^{\text {a }}$ Conferência Internacional de História de Empresas.

RICUPERO, Bernardo (2016). Ariel na América: Viagens de uma Ideia. INTERSEÇÕES, Rio de Janeiro, v. 18 n. 2, p. 372-407.

SOUSA. Tomé de (1553). Carta de Tomé de Sousa a el-rei com muitas notícias das terras do Brasil. Cidade do Salvador. In As Gavetas da Torre do Tombo, 1971. Disponível em < http://repositorio.ul.pt/bitstream/10451/34708/1/GavetaIX.pdf $>$ Acesso em 12 de jan de 2019.

VENANCIO, Gisele e André Furtado (2016). Passados (im)perfeitos ou a ótica buarqueana sobre o Império do Brasil na América Revista Brasileira de História. São Paulo.

VERÍSSIMO, José (1986). Cultura, Literatura e Política na América Latina. São Paulo: Brasiliense.

WEGNER, Robert (2006). Um ensaio entre o passado e o futuro. In Raízes do Brasil, Holanda, Rio de Janeiro: Companhia da Letras, Edição Comemorativa.

WEINBERG, Liliana (2001). Ensayo e interpretación de América. In: VEGA, Mercedes de (coord.). La literatura hispano-americana. México: Secretará de Relaciones Exteriores. Dirección General del Acervo Histórico Diplomático.

Artigo recebido em 13 de abril de 2020.

Aprovado em 09 de junho de 2020.

DOI: $10.12957 /$ intellectus.2020.48115 